\title{
Modeling of Lightning Events using WRF-derived Microphysical Parameters
}

\author{
Md. Ashraful Islam¹, Javed Meandad ${ }^{1}$, Saurav Dey Shuvo ${ }^{1}$ and Alamgir Kabir ${ }^{2}$ \\ ${ }^{1}$ Department of Meteorology, University of Dhaka, Dhaka 1000, Bangladesh \\ ${ }^{2}$ Department of Physics, University of Dhaka, Dhaka 1000, Bangladesh \\ Manuscript received: 26 September 2020: accepted for publication: 10 January 2021
}

\begin{abstract}
Numerical simulation of lightning events in Bangladesh has been carried out by using Weather Research and Forecasting Model with Advanced Research Dynamic solver (WRF-ARW). Three major lightning events have been considered for the case study; Case_1, lightning occurrence in Netrokona district in March 24 2017, Case_2, lightning event in Barishal district in April 23 2017, and case_3, lightning event in Sherpur district in April 29, 2018. The model simulation was run in $9 \mathrm{~km}$ and $3 \mathrm{~km}$ of horizontal resolution using six hourly NCEP-FNL datasets. Yonsei University (YSU) PBL scheme, Rapid Radiative Transfer Model (RRTM) long-wave scheme for radiation, and KainFritsch cumulus parameterization scheme is used for this study. The obtained results from the simulation could reasonably capture the lightning condition of the atmosphere for all the three cases. The WRF simulation give reasonable agreement with the available observational data with some spatial and temporal variations, for example the Convective Available Potential Energy (CAPE) values observed are $1299 \mathrm{~J} / \mathrm{Kg}, 3150 \mathrm{~J} / \mathrm{kg}, 1221 \mathrm{~J} / \mathrm{kg}$ and CAPE values simulated are $1618 \mathrm{~J} / \mathrm{kg}, 3275 \mathrm{~J} / \mathrm{kg}$ and $1023 \mathrm{~J} / \mathrm{kg}$ for case_1, case_2 and case_3 respectively. The regression analysis of the flash count with the microphysical parameters is also studied. It is found that there is strong correlation between the lightning flash counts with the microphysical parameters. This study will help to understand the lightning better and will help to design a better lightning forecasting system.
\end{abstract}

Keywords: WRF, Reflectivity, Regression, Microphysics, Flash counts

\section{INTRODUCTION}

Lightening injury is one of the leading causes of weather-related death all over the world. Every year, over 2000 peoples suffer from lightening related injury all over the world. Lightning is one of the most dangerous natural hazards in Bangladesh. Due to the recent increasing rate of lightning related injuries and deaths, the government declared lightning as a natural disaster of Bangladesh in 2016. About 114 people have been killed by lightning per year till 1990 to 2016 in Bangladesh (Dewan et al., 2017). In developing countries like Bangladesh most of the people died from cloud to ground lightning strikes in the agricultural fields (Holle, 2016), as most of the people works in the field during the rain to have maximum use of rain water during the monsoon season. Maximum number of the lightning events occur in the northeastern part of Bangladesh during the month of March, April, and May (MAM) over Sunamganj district, due to the onset of Indian monsoon (Albrecht et al., 2009; Das, 2010). Though maximum lightning event occurs at the afternoon, but

Corresponding author: Alamgir Kabir

E-mail: alamgir.kabir@du.ac.bd

DOI: https://doi.org/10.3329/dujees.v8i2.54838 most of the lightning related injuries and death occurred in Bangladesh during early morning and early evening (Dewan et al., 2017).

Lightning is the spark of electricity between clouds, between clouds and the ground, and in intra-cloud. It occurs when two clouds with different electric charge come very close to each other. The discharge of electric charges has occurred tremendously at high speed (Das, 2017), and it generates the lightning by the breakdown of electric fields into the thunderstorm systems. The updraft speed and density of the ice particles initiate and maintain the electrical activity inside thunderstorms. (Williams, 2001). Several authors (Mansell and Ziegler, 2013; Stolz et al., 2015; Williams et al., 2002; Yuan et al., 2011) have expressed that the aerosols content in the atmosphere act as cloud condensation nuclei and they might enhance lightning process by reducing the warm rain coalescence. The most common type of lightning is the intra-cloud lightning in high altitude. Because of its unique orography, mountain gradient, geographical locations and some local reasoning, the lighting pattern in Bangladesh may differ from the neighbouring countries. (Nath et al. 2009; Siingh et al. 2014; Tinmaker and Chate, 2013).

More than 2000 active thunderstorms occur around the world in every second and it produces roughly 100 lightning flashes (Brooks, 1925). It is found that the temporal variability of lightning frequency over Indian 
region is related to convective activity. The geographical position, large-scale circulations, and the gradient of land also play important role to generate lightning flashes (Kandalgaonkar et al., 2005; Ranalkar and Chaudhari, 2009). Global lightning activity might be changed in the future as a result of global warming ( Williams, 1992), and the El Niño-Southern Oscillation (ENSO) phenomena (Goodman et al., 2000; Goodman and Christian, 1993; Hamid et al., 2001) are also responsible for the fluctuation of frequency of lightning flash counts and its seasonal variations. Kar et al. (2009) has shown that the lightning pattern can be depended on the forest to land ratio and it is shown that the lightning activity across the world is expected to increase enormously with the increase of temperature (Williams, 1992, 1994; 2005). (Nath et al. 2009; Reeve and Toumi 1999) have shown that an increase of $1^{\circ} \mathrm{C}$ of wet-bulb temperature could result of $40 \%$ increases of lightning activity.

The unpredictable nature of lightning makes it more dangerous natural hazards on earth than any other natural hazard (Holle et al., 1999). Maybe, it is possible to save lives and properties by an Early Warning System (EWS). It is self-evident that a timely early warning for lightning activity can minimize the potential loss and is a basic component of any disaster risk reduction strategy (Gomes et al., 2006). Lightning awareness programmes in Bangladesh were started in 2004, which trained mainly the schoolteachers so that they can proclaim the knowledge to the students and common people (Battan, 1965). To save the life and causalities of people we need to build a very accurate forecasting techniques and effective awareness programmes. However, so far very few studies are found related to lightening over Bangladesh. All these studies showed that both the frequency of lightning and lightning related injuries is increasing day by day in Bangladesh. Effective forecasting can minimize the loss of lives and property. Study of the electric field of thunderstorms by sounding experiment is increasing (Piepgrass et al., 1982), but it has limitations in study of weak electric fields.

Various types of statistical techniques have been used by scientist and meteorologist to build up forecasting model for thunderstorms and lightning (Battan, 1965; Dewan et al., 2017; Murugavel et al., 2014; Piepgrass et al., 1982; Williams, 1995). Multiple linear regression, classification and regression trees (CART) and binary logistic regression are some of the widely used statistical models (Murugavel et al., 2014).
For continuous predictands, the most commonly used method is multiple linear regression (MLR), however, for discrete events binary logistic regression (BLR) is more widely used (Battan, 1965). These methods attempt to quantify the relationship between a set of predictors and thunderstorm probability or lightning frequency (Piepgrass et al., 1982). (Dewan et al., 2017) parameterized lightning flash rate as a linear function of the upward cloud ice mass flux at $440 \mathrm{hPa}$. (Williams, 1995) and (Murugavel et al. 2014) researched the relationships between lightning activity and tropical cyclone (TC) intensity for systems near land and in the open ocean using the World Wide Lightning Location Network (WWLLN) data.

This paper study the relationship between cloud microphysical parameters and lightning activity for Bangladesh based on selected parameters on which lightning shows higher sensitivity. Weather research and forecast (WRF) model with suitable microphysics option is used for the simulation of lighting events. Correlation and Regression analysis are performed for the cases to find out correlations between microphysical parameters and lighting occurrence.

\section{MODEL DESCRIPTION AND MICROPHYSICAL PARAMETERS}

The non-hydrostatic fully compressible WRF model version 4.0.3 developed by National Center for Atmospheric Research (NCAR) is used in this study. The detail description of the model and microphysical parameters is mentioned in the Table 1.

Table 1 : Brief Description of Model Aspects and Physical Options

\begin{tabular}{|l|l|}
\hline Model Properties & Specification \\
\hline WRF version & 4.0 .3 \\
\hline Spatial Resolution & $9 \mathrm{~km}$ and $3 \mathrm{~km}$ \\
\hline Vertical level & 35 \\
\hline Dynamics & Non-hydrostatics \\
\hline Run period & 24 hours \\
\hline Map Projection & Mercator \\
\hline $\begin{array}{l}\text { Initial and Lateral } \\
\text { Boundary }\end{array}$ & $\begin{array}{l}1^{\circ} \mathrm{X} 1^{\circ} \text { six hourly Final Reanalysis } \\
\text { (FNL) data }\end{array}$ \\
\hline PBL & Yonsei University (YSU) scheme \\
\hline Radiation & $\begin{array}{l}\text { Rapid Radiative Transfer Model } \\
\text { (RRTM) long-wave scheme, Dudhia } \\
\text { shortwave scheme }\end{array}$ \\
\hline $\begin{array}{l}\text { Cumulus } \\
\text { Parameterization }\end{array}$ & $\begin{array}{l}\text { Kain-Fritsch cumulus parameterization } \\
\text { scheme used in course domain }\end{array}$ \\
\hline Microphysics & $\begin{array}{l}\text { Morrison double-moment scheme } \\
\text { with CESM aerosol. }\end{array}$ \\
\hline
\end{tabular}




\section{DATA USED}

The imaging sensor of GeoTIFF format (IMG_WV) data is used in this study to compare with the qvapor (vapor water mixing ratio) which is derived from WRF model simulation. This dataset contains Integrated Water Vapor count (IWV) estimates derived from GPS (INSAT-3DR) receivers and stored in website (https://mosdac.gov.in). The Raster Data (GeoTIFF) is stored in mosdac website as point data. This GeoTIFF format point data firstly converted into grid format (latlon) data by using GIS (Geographic Information System). Then Grid format data converted into netCDF format data. Then the netCDF data (Gridded) finally visualized using Grid Analysis and Display System (GrADs) tool. The International Space Station (ISS) Lightning Imaging Sensor (LIS) dataset have been used in this study to calculate and visualize the lightning flash count which is available from 2017 to the present time. This dataset includes non-quality-controlled science data, non-quality-controlled background data, near-real time science data, and near-real time background data. (http:// dx.doi.org/ 10.5067/ LIS/ ISSLIS/ DATA205). In this study, the Lightning Imaging Sensor based International Space Station (LIS_ISS) data has been used to select the cases based on lightning flash counts. For model run, FNL $\left(1^{\circ} * 1^{\circ}\right)$ data is used. This data is built by National Centre for Atmospheric Research (NCAR) and stored in website (https://rda.ucar.edu/datasets/ds083.2/index.html\#sfolwl-/data/ds083.2?g=2).

\section{STUDY AREA}

Recently occurred three major lightning events are studied in this paper. The $1^{\text {st }}$ event has occurred on March 24, 2017 at Atpara in Netrokona district, (latitude of $24.8^{\circ} \mathrm{N}$ and longitude $90.8^{\circ} \mathrm{E}$ ). A major lightning event has occurred at 22:47:55 UTC in the mentioned location. The $2^{\text {nd }}$ event has occurred on April 23, 2017 at Daulatkhan in Barishal district (latitude of $22.6^{\circ} \mathrm{N}$ and longitude $90.6^{\circ} \mathrm{E}$ ). A lightning event has occurred at 11:10:02 UTC in this location. For the $3^{\text {rd }}$ event we have chosen a lightning event on April 29, 2018 at Jhenaigati Upazila in Sherpur district (latitude of $25.2^{\circ} \mathrm{N}$ and longitude $90^{\circ} \mathrm{E}$ ). At 21:57:13 UTC a lightning has occurred in the location at the mentioned time. All the three events are shown in Figure 1.

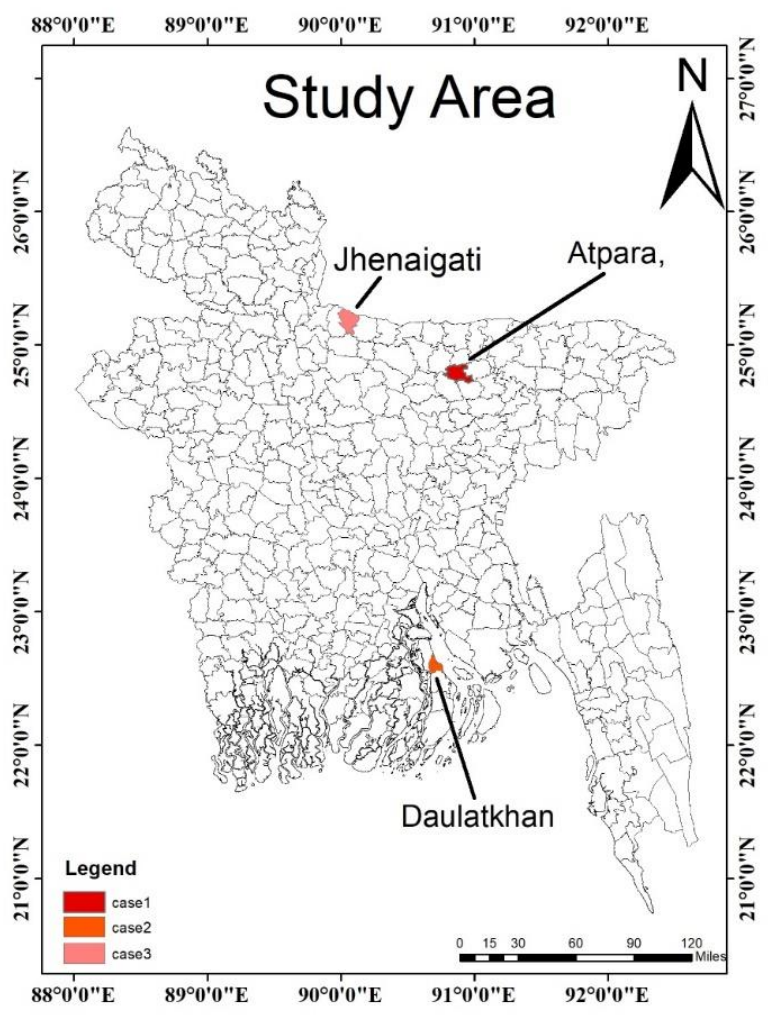

Figure 1: Location of the Three Cases Considered for this Study. Case_1 is in Atpara, Netrokona is Shown in Red, case_2 is in Daulatkhan, Barishal is Shown in Orange, and case_3 is in Jhenaigati, Sherpur is Shown in Yellow Colour

\section{RESULTS AND DISCUSSIONS}

\section{Comparison of WRF model simulated Vapour water mixing ratio and Satellite derived Water vapour Count}

For the case_1 the WRF model simulated Vapour water mixing ratio (qvapor) and INSAT-3DR observed water vapour count are presented in Figure 2(a) and Figure 2(b) respectively. Both the simulated vapour water mixing ratio and observed water vapour count shows a large value over the north-east parts of Bangladesh on $24^{\text {th }}$ March 2017. The lightning flashes was observed over Netrokona district at 2245 UTC where simulated vertically integrated vapour water mixing ratio is $0.1 \mathrm{Kg} / \mathrm{Kg}$ and INSAT-3DR observed water vapour count is 970 at 2245 UTC. 


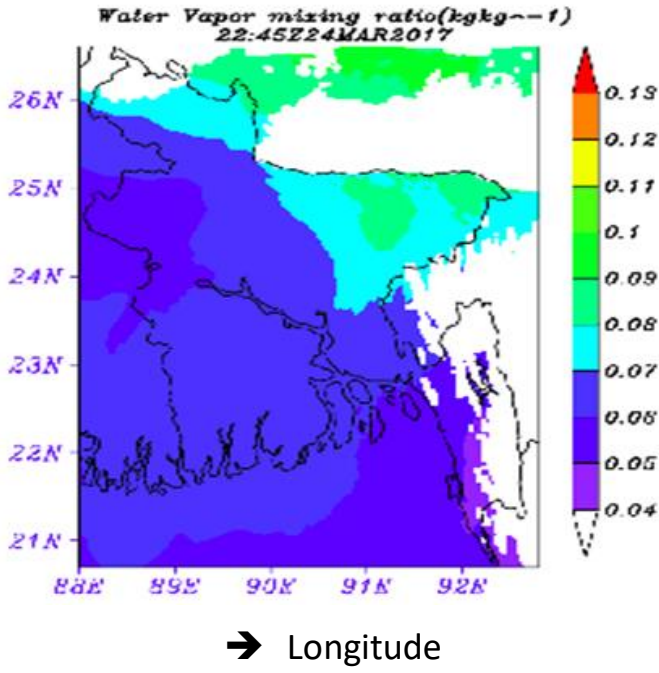

(a)

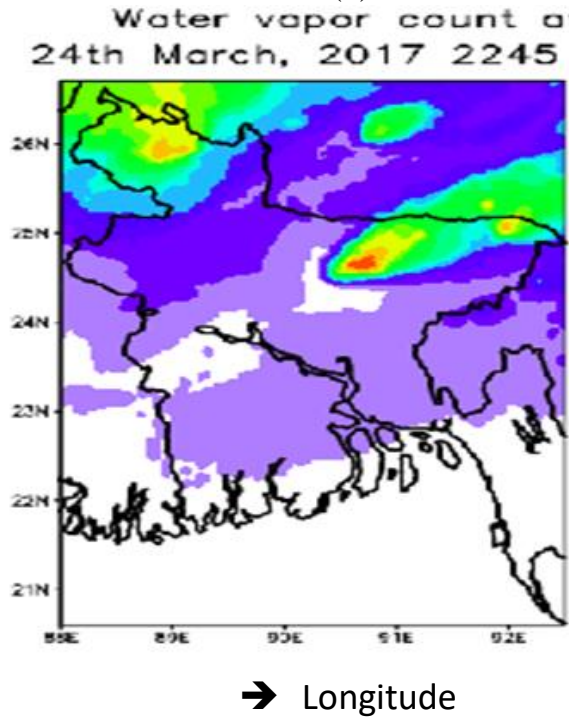

(b)

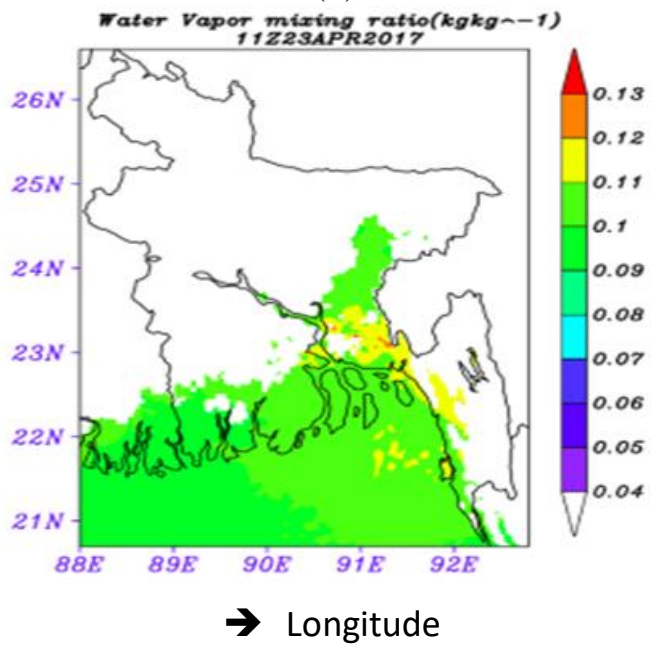

(c)

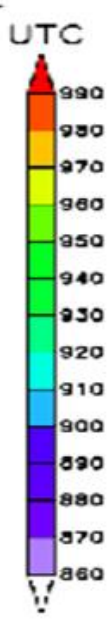

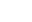

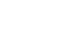


Some high to moderate vapour water mixing ratio is also present over east and north-east part of Bangladesh but the maximum coverage over northeastern part. Gusty wind of speed $40 \mathrm{kts}$ was present over Dhaka, Srimangal, Cumilla, Badalgachi, Bogura, Tarash, Mymensingh, Chattogram and the direction were north-westerly during the time of lightning. The model driven vapour water mixing ratio and INSAT3DR observed water vapour count maximum shows the same area $\left(90.8^{\circ} \mathrm{E}\right.$ and $24.8^{\circ} \mathrm{N}$, Atpara, Netrokona) where total maximum lightning was occurred.

For case_2 Vapour water mixing ratio is concentrated over the south-east part and south-east part to eastern part of Bangladesh which is observed from both the WRF model simulated vapour water mixing ratio (qvapour) as shown in Figure 2(c) respectively. As shown in Figure 2(d), The Satellite INSAT-3DR observed water vapour count is observed maximum in lower southern part of Bangladesh near the total maximum lightning occurrence place. The model simulated vapour water mixing ratio (qvapour) shows a value of $0.12 \mathrm{Kg} / \mathrm{Kg}$ near the total maximum lightning occurrence place (Daulatkhan, Barishal) at 1100 UTC. The Satellite INSAT-3DR observed water vapour count at the location of lightning events at 0645 UTC is approximately 920 . This dissimilarity in vapour water mixing ratio and water vapour count may be attributed to the spatial and temporal (4:15 hours) deviation of WRF model data and observation data.

In the case_3, Vapour water mixing ratio was observed all over Bangladesh by both the simulation and the Satellite INSAT-3DR observation. It shows $0.09 \mathrm{Kg} / \mathrm{Kg}$ value of vapour water mixing ratio (qvapor) all over Bangladesh presented in figure 1(e) and the Satellite INSAT-3DR observed water vapour count (Figure 2(f)) shows 870 to 880 at 1715 UTC. Maximum total lightning (64) occurrence places is Sherpur (Jhenaigati) where vapour water mixing ratio $0.09 \mathrm{Kg} / \mathrm{Kg}$ and INSAT-3DR observed water vapour count shows 870 to 880 at 1715 UTC. In this case, the Total maximum lightning occurrence, WRF model simulated vapour water mixing ratio and the Satellite INSAT-3DR data water vapour count has dissimilarity. The total maximum lightning occurrence place indicates high amount of vapour mixing ratio, but water vapour count indicates low. The dissimilarity in vapour water mixing ratio and water vapour count over the total maximum lightning occurrence place because of the temporal (4:30 hours) deviation of WRF model simulated vapour water mixing ratio and the Satellite observed water vapour count.

The overall WRF model simulated water vapour mixing ratio (qvapor) and the Satellite INSAT-3DR observed water vapour count shows positive correlation. As the temporal resolution of both total lightning flashes, vapour water mixing ratio and water vapour count are not same, some deviations in terms of position are seen in some cases.

Table 2: LIS_ISS Satellite Based Maximum Flashes Count at Occurrence Place According to Three Cases.

\begin{tabular}{|l|l|l|l|l|l|l|}
\hline Case & Date & Time & Latitude & Longitude & $\begin{array}{l}\text { Flash } \\
\text { Counts }\end{array}$ & Place \\
\hline Case_1 & 24.03 .2017 & $\begin{array}{l}2247 \\
\text { UTC }\end{array}$ & $90.8^{\circ} \mathrm{E}$ & $24.8^{\circ} \mathrm{N}$ & 156 & $\begin{array}{l}\text { Atpara, } \\
\text { Netrokona }\end{array}$ \\
\hline Case_2 & 23.04 .2017 & $\begin{array}{l}1110 \\
\text { UTC }\end{array}$ & $90.6^{\circ} \mathrm{E}$ & $22.6^{\circ} \mathrm{N}$ & 64 & $\begin{array}{l}\text { Daulatkhan, } \\
\text { Barishal }\end{array}$ \\
\hline Case_3 & 29.04 .2018 & $\begin{array}{l}2157 \\
\mathrm{UTC}\end{array}$ & $90.0^{\circ} \mathrm{E}$ & $25.2^{\circ} \mathrm{N} 2$ & 14 & $\begin{array}{l}\text { Jhenaigati, } \\
\text { Sherpur }\end{array}$ \\
\hline
\end{tabular}

Model simulated Maximum Reflectivity analysis at the total maximum lightning occurrence place

Area of lower radar reflectivity at colder temperature, e.g., area of $20 \mathrm{dBZ}$ at $-40^{\circ} \mathrm{C}$, is also highly correlated with lightning frequency (W. Xu et al., 2010). Maximum reflectivity (max_dbz) shows positive relation with the lightning flashes. As a result, in this study Maximum reflectivity is analyzed for selected cases and correlate with the lightning occurrence.

In the first case on $24^{\text {th }}$ March 2017, reflectivity concentrated over the North-East part of the country. It shows (25-40 dBZ) values over Sylhet region. But Lightning flashes is concentrated over the Netrokona District where maximum reflectivity is $0 \mathrm{dBZ}$ (Figure 3a). First case is $24^{\text {th }}$ March 2017 , where highest (156 flashes) lightning activity occurs at $24.8^{\circ} \mathrm{N}$ and $90.8^{\circ}$ E at 2247 UTC (Table 2). Maximum reflectivity is proportional to microphysical parameters. In this case, at total maximum lightning occurrence place (Atpara, Netrokona) indicates $0 \mathrm{DBZ}$ reflectivity that means in that place cloud microphysical parameters had a little contribution of occurring lightning. Here, total lightning flash count and maximum reflectivity has some temporal deviation (0:02 hours). 


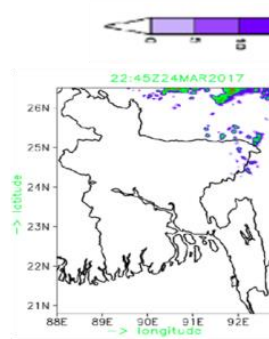

(a)

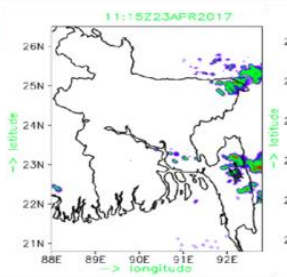

(b)

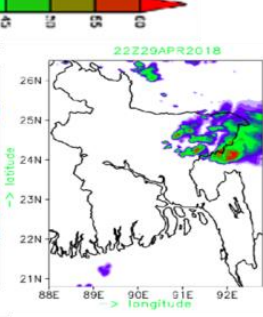

(c)
Figure 3: Rainfall Driven from WRF Model on the Individual Cases at the Time of Intense Storm Occurrence (a) Case_1, (b) Case_2, and (c) Case_3

In second Case on $23^{\text {rd }}$ April 2017, maximum reflectivity concentrated over the north-east part and south-east past of the country. It shows (25-55 DBZ) values over the Sylhet region and Rangamati, Bandarban, Chandpur, Barishal, Dhaka and Madaripur district and at the location of $22.6^{\circ} \mathrm{N}$ and $90.6^{\circ} \mathrm{E}$ at time 1115 UTC shows 30 DBZ (Figure 3b). In second case $23^{\text {rd }}$ April 2017, where highest (64 flashes) lightning activity occurs at $22.6^{\circ} \mathrm{N}$ and $90.6^{\circ} \mathrm{E}$ at 1110 UTC (Table 2). Maximum lightning Flashes count in Barishal district (Daulat khan) where the maximum reflectivity is 30-35 DBZ. Maximum reflectivity indicates that in the total maximum lightning occurrence place cloud microphysical parameters is high that had a good contribution of occurring lightning at $22.6^{\circ} \mathrm{N}$ and $90.6^{\circ} \mathrm{E}$ location. In this case, here also some temporal deviation (0:05 hours) for total lighting flash count and maximum reflectivity are present.

In third Case on $29^{\text {th }}$ April 2018, maximum reflectivity concentrated over north-east part of Bangladesh. It Shows (15-60 DBZ) values of reflectivity over Sylhet, Sunamganj, Srimangal, Habiganj, Moulvibazar, and adjacent area of Bangladesh (Figure 3c). Maximum total lightning (14) occurrence place is Sherpur (Jhenaigati) where maximum reflectivity shows 0 (zero) DBZ. In this case, at total maximum lightning occurrence place (Jhenaigati, Sherpur) indicates $0 \mathrm{DBZ}$ reflectivity that means in that place cloud microphysical parameters had a little contribution of occurring lightning. Here, total lightning flash count and maximum reflectivity has some temporal deviation (0:03 hours).

In this study, only one case shows positive correlation between light flashes and model derived maximum reflectivity and other two cases show low with some spatial and temporal deviation. Here WRF model driven reflectivity and DWR reflectivity show positive correlation and also some spatial error due to temporal error. As the temporal resolution of both lightning flashes and maximum reflectivity are not same some deviations in terms of position are seen in some cases. Over all, it shows a positive correlation with lightning activity and model derived maximum reflectivity with some spatial and temporal deviation.

\section{Model simulated Convective available potential energy analysis}

The updraft speed and vertical distribution of hydrometeors is determined mostly by the magnitude and vertical distribution of Convective Available Potential Energy (CAPE). CAPE is also responsible for the charge generation processes in the thunderclouds (Williams, 1995). The magnitude of CAPE is expected to show a good relationship with the lightning activity. It is showed by (Murugavel et al., 2014) that the lightning activity and CAPE are well correlated during the monsoon as compared to the other season.
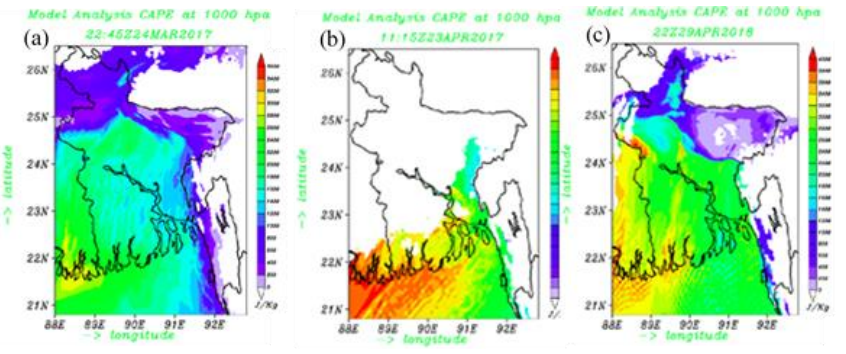

Figure 4: Convective Available Potential Energy (CAPE) at Time of Storm Intensification of the Individual Cases (a) Case_1 (b) Case_2 (c) Case_3

In the first case on $24^{\text {th }}$ March 2017, the model simulation gives the maximum concentration of cape value over south west part and upper central part of Bangladesh at 2245 UTC during the intense storm, and the value got decreased along one move to the northeast part of the country. During the intense lightning event the maximum flash count was 156 at $90.8^{\circ} \mathrm{E}$ and $24.8^{\circ} \mathrm{N}$, and the simulated CAPE value is found to be larger than $1200 \mathrm{~J} / \mathrm{Kg}$ as shown in Figure 4(a). This large CAPE value is an indication of unstable atmosphere, since the value of $1000 \mathrm{~J} / \mathrm{Kg}$ or more is sufficient for the occurrence of a severe thunderstorm.

In case_2 on $23^{\text {rd }}$ April 2017, maximum lightning flash count occurrence at location $90.6^{\circ} \mathrm{E}$ and $22.6^{\circ} \mathrm{N}$ was recorded. The simulated CAPE value obtained from WRF model at the location of the event is 
greater than $3500 \mathrm{~J} / \mathrm{Kg}$ which is an indication of extremely unstable atmosphere as shown in the Figure 4(b). Maximum CAPE value was observed in the south-west part of Bangladesh and decrease toward the north-east direction. The maximum CAPE value and the lightning activity have occurred at the same time and location, so the model simulation is capable to capture the lightning event accurately.

In the case 3 on $29^{\text {th }}$ April 2018, our model simulated CAPE value is found to be larger than 1000 $\mathrm{J} / \mathrm{Kg}$ at the location of $90^{\circ} \mathrm{E}$ and $25.2^{\circ} \mathrm{N}$ is represented in Figure 4(c), and the lightning flash count is observed to be 14. The maximum value of CAPE occurs at the south-west part of Bangladesh, and the value is greater than $3400 \mathrm{~J} / \mathrm{Kg}$. So, for the case_3 the maximum CAPE value and the lightning activity does not occurs at the same location. This $1000 \mathrm{~J} / \mathrm{Kg}$ of CAPE value indicates that maximum lightning occurrence place has marginally unstable atmosphere during the lightning event at 2200 UTC (Figure 4(c)). The temporal deviation of CAPE simulation may be responsible for the deviation of maximum CAPE occurrence and the lightning event. In this case the model simulation can capture the lightning event with some deviation.

Although only one case maximum cape value is deviated from the maximum lightning occurrence location and lightning event occurrence, all the other cases showed almost exact location of CAPE maxima and same kind of distribution.

\section{Upper troposphere atmospheric condition}

The meteorological condition of the upper air can be obtained from the Skew-T diagram. Temperature, Pressure, Dry Adiabats, Moist (or Saturated) Adiabats, Mixing Ratio, Wind Staff can be obtained from the Skew-T diagram.

For case_1, maximum flashes count (156 flash) in occurrence place $\left(90.8^{\circ} \mathrm{E}\right.$ and $\left.24.8^{\circ} \mathrm{N}\right)$ at 22457 UTC, the skew-T diagram represents lifted condensation level at $950 \mathrm{hPa}$ level and the temperature at that level is $22.9^{\circ} \mathrm{C}$ (dew point temperature $18^{\circ} \mathrm{C}$ ) during the time of intense storm event. The CAPE value at the time of the event is $1633 \mathrm{~J} / \mathrm{Kg}$, and the LI index is -5 , which represents a moderately unstable atmosphere. The observed value of lifted condensation level is $900 \mathrm{hpa}$, and the air temperature is $26.5^{\circ} \mathrm{C}$ as observed from data available by radiosonde experiments $25^{\text {th }}$ March
2017, at $0000 \mathrm{UTC}$ at the location of $90.38^{\circ} \mathrm{E}$ and $23.77^{\circ} \mathrm{N}$. Thunderstorm is more likely to happen. The thermodynamic condition 15 minutes before the lightning event at the same location gave the CAPE value of $1618 \mathrm{~J} / \mathrm{kg}$ and LI index is -5 , that means the atmosphere was unstable at that location even 15 minutes before the lightning. The observed value of CAPE is $1299 \mathrm{~J} / \mathrm{Kg}$ with the same experiments.

Table 3: Thermodynamic Condition of the Events. Available Observed Values are Shown in the Parenthesis

\begin{tabular}{|l|l|l|l|l|l|l|}
\hline Time & Case & $\begin{array}{l}\text { lfc } \\
\text { At pressure } \\
\text { level } \\
\text { (hpa) }\end{array}$ & $\begin{array}{l}\text { Air Temp. } \\
\left({ }^{\circ} \mathrm{C}\right)\end{array}$ & $\begin{array}{l}\text { Dew } \\
\text { Point } \\
\text { Temp } \\
\left({ }^{\circ} \mathrm{C}\right)\end{array}$ & $\begin{array}{l}\text { LI } \\
\text { Index }\end{array}$ & $\begin{array}{l}\text { CAPE(J/Kg) at } \\
\text { Most Unstable } \\
\text { Level }\end{array}$ \\
\hline $\begin{array}{l}15 \\
\text { minutes } \\
\text { before } \\
\text { the } \\
\text { lightning }\end{array}$ & Case_1 & 950 & 23.1 & 18.3 & -5 & 1618 \\
\cline { 2 - 7 } & Case_2 & 1000 & 29.2 & 25.3 & -9 & 3275 \\
\hline \multirow{2}{*}{$\begin{array}{l}\text { At the } \\
\text { time of } \\
\text { the } \\
\text { lightning }\end{array}$} & Case_1 & 1000 & 23.5 & 21.4 & -3 & 1023 \\
\cline { 2 - 7 } & Case_2 & $1000(925)$ & $29(24.5)$ & 25.3 & $\begin{array}{l}-9(- \\
5.68)\end{array}$ & $3150(483.3)$ \\
\cline { 2 - 7 } & Case_3 & 950 & 23.5 & 21.5 & -3 & 1221 \\
\hline
\end{tabular}

In the case 2 on $23^{\text {rd }}$ April 2017, at Daulatkhan, Barishal $\left(90.6^{\circ} \mathrm{E}\right.$ and $\left.22.6^{\circ} \mathrm{N}\right)$, the lifting condensation level is presents at $1000 \mathrm{hpa}$ and temperature in this level is $29^{\circ} \mathrm{C}$ (dew point temperature $25.3^{\circ} \mathrm{C}$ ) during the lightning (64 flashes) events. According to skew-T diagram CAPE value was $3150 \mathrm{~J} / \mathrm{Kg}$ and the $\mathrm{LI}$ index was -9 which means the atmosphere was extremely unstable during the event. The observed value of lifted condensation level is $925 \mathrm{hpa}$, and the air temperature is $24.5^{\circ} \mathrm{C}$ as observed from data available by radiosonde experiments $23^{\text {rd }}$ April 2017, at 1200 UTC at the location of $90.38^{\circ} \mathrm{E}$ and $23.77^{\circ} \mathrm{N}$. The thermodynamic condition at the same location but 15 before the lightning event shows the value of the CAPE was $3275 \mathrm{~J} / \mathrm{Kg}$ and LI index was -9 , which indicates that the atmosphere was extremely unstable at the location of the events even 15 minutes earlier than the lightning occurrence.

In the case 3 , on $29^{\text {th }}$ April 2018 at 2157 UTC at Jhenaigati, Sherpur $\left(90^{\circ} \mathrm{E}\right.$ and $\left.25.2^{\circ} \mathrm{N}\right)$ a lightning event with total flashes 14 counts occurred. Figure 5f, represents the Skew-T diagram at 2200 UTC at the location of the event. It shows the lifting condensation level is $950 \mathrm{hpa}$ and air temperature at this level is $23.4^{\circ} \mathrm{C}$ (dew point temperature $21.5^{\circ} \mathrm{C}$ ). The CAPE $(1221 \mathrm{~J} / \mathrm{Kg})$ value indicates moderate 
unstable atmosphere, but LI index (-3) indicates marginally unstable atmosphere. The thermodynamic condition at the same location as of the case_3 but 15 minutes before shows the CAPE value is $1023 \mathrm{~J} / \mathrm{Kg}$ and LI index is -3 which indicates that the atmosphere was moderately unstable even 15 before the lightning.

From the observation on $24^{\text {th }}$ March 2017, the LCL present at $900 \mathrm{hPa}$ level and the temperature at that level is $26.5^{\circ} \mathrm{C}$. CAPE value is $1299 \mathrm{~J} / \mathrm{Kg}$ which indicates moderate unstable, but LI index $(-0.10)$ indicates stable atmosphere at 2500 UTC. Comparison to Model driven values of CAPE and LI index using Skew-T diagram it shows CAPE $(1633 \mathrm{~J} / \mathrm{Kg})$ and LI index $(-5)$ both indicates moderate unstable atmosphere. As there are some spatial $\left(0.42^{\circ} \mathrm{E}\right.$ and $\left.1.04^{\circ} \mathrm{N}\right)$ and temporal (01:15 hours) variation thus this dissimilarity could be occurred.

On $23^{\text {rd }}$ April 2017, model and observation shows dissimilarities in terms of thermodynamic condition of the atmosphere. Observation shows CAPE $(483.3 \mathrm{~J} / \mathrm{Kg})$ which indicates marginally unstable atmosphere and LI index (-5.68) indicates very unstable atmosphere condition over Dhaka at the time of 1200 UTC, but model shows extremely unstable condition of the atmosphere according to CAPE value $(3150 \mathrm{~J} / \mathrm{Kg}$ ) and LI index (-9). Spatial variation between model and observation in this case is $0.22^{\circ} \mathrm{E}$ and $1.16^{\circ} \mathrm{N}$ and the temporal variation is 45 minutes, which may be responsible for this dissimilarity.

\section{Correlation and regression analysis of three cases}

The strength of pairs of variables can be obtained by correlation analysis. Karl Pearson coefficient of correlation will always obtain a value between -1 and +1 . In this paper we study the correlation analysis between flash counts and microphysical parameters. The results are summarized in Table 4.
Table 4: Correlations between Flash Count and Other Microphysical Parameters

\begin{tabular}{|c|c|c|c|c|}
\hline \multirow{5}{*}{\begin{tabular}{|l|} 
\\
Lightnin \\
g flash \\
count \\
and \\
Snow \\
mixing \\
ratio
\end{tabular}} & \multicolumn{4}{|l|}{ Correlations } \\
\hline & & & $\begin{array}{l}\text { Total_Flash_ } \\
\text { Counts }\end{array}$ & $\begin{array}{l}\text { qsno } \\
\text { w } \\
\end{array}$ \\
\hline & \multirow[t]{3}{*}{$\begin{array}{l}\text { Total_Flash_Cou } \\
\text { nts }\end{array}$} & \begin{tabular}{|l|} 
Pearson \\
Correlation
\end{tabular} & 1 & 0.982 \\
\hline & & \begin{tabular}{|l} 
Sig. (2-tailed) \\
\end{tabular} & & 0.121 \\
\hline & & $\mathrm{N}$ & 3 & 3 \\
\hline ratio & \multirow[t]{3}{*}{ qsnow } & $\begin{array}{l}\text { Pearson } \\
\text { Correlation } \\
\end{array}$ & 0.982 & 1 \\
\hline & & Sig. (2-tailed) & 0.121 & \\
\hline & & $\mathrm{N}$ & 3 & 3 \\
\hline \multirow{6}{*}{$\begin{array}{l}\text { Lightnin } \\
\mathrm{g} \text { flash } \\
\text { count } \\
\text { and } \\
\text { Graupel } \\
\text { mixing } \\
\text { ratio }\end{array}$} & \multirow[t]{3}{*}{$\begin{array}{l}\text { Total_Flash_Cou } \\
\text { nts }\end{array}$} & $\begin{array}{l}\text { Pearson } \\
\text { Correlation } \\
\end{array}$ & 1 & 0.981 \\
\hline & & \begin{tabular}{|l} 
Sig. (2-tailed) \\
\end{tabular} & & 0.125 \\
\hline & & $\mathrm{N}$ & 3 & 3 \\
\hline & \multirow[t]{3}{*}{ qgraup } & $\begin{array}{l}\text { Pearson } \\
\text { Correlation } \\
\end{array}$ & 0.981 & 1 \\
\hline & & Sig. (2-tailed) & 0.125 & \\
\hline & & $\mathrm{N}$ & 3 & 3 \\
\hline \multirow{6}{*}{$\begin{array}{l}\text { Lightnin } \\
\text { g flash } \\
\text { count } \\
\text { and } \\
\text { Cloud } \\
\text { mixing } \\
\text { ratio }\end{array}$} & \multirow[t]{3}{*}{$\begin{array}{l}\text { Total_Flash_Cou } \\
\text { nts }\end{array}$} & $\begin{array}{l}\text { Pearson } \\
\text { Correlation } \\
\end{array}$ & 1 & 0.999 \\
\hline & & \begin{tabular}{|l|} 
Sig. (2-tailed) \\
\end{tabular} & & 0.032 \\
\hline & & $\mathrm{N}$ & 3 & 3 \\
\hline & \multirow[t]{3}{*}{ qcloud } & $\begin{array}{l}\text { Pearson } \\
\text { Correlation }\end{array}$ & 0.999 & 1 \\
\hline & & Sig. (2-tailed) & 0.032 & \\
\hline & & $\mathrm{N}$ & 3 & 3 \\
\hline \multirow{6}{*}{$\begin{array}{l}\text { Lightnin } \\
\text { g flash } \\
\text { count } \\
\text { and } \\
\text { water } \\
\text { vapour } \\
\text { mixing } \\
\text { ratio }\end{array}$} & \multirow[t]{3}{*}{$\begin{array}{l}\text { Total_Flash_Cou } \\
\text { nts }\end{array}$} & \begin{tabular}{|l} 
Pearson \\
Correlation \\
\end{tabular} & 1 & 0.920 \\
\hline & & \begin{tabular}{|l|} 
Sig. (2-tailed) \\
\end{tabular} & & 0.257 \\
\hline & & $\mathrm{N}$ & 3 & 3 \\
\hline & \multirow[t]{3}{*}{ qvapour } & $\begin{array}{l}\text { Pearson } \\
\text { Correlation } \\
\end{array}$ & 0.920 & 1 \\
\hline & & Sig. (2-tailed) & 0.257 & \\
\hline & & $\mathrm{N}$ & 3 & 3 \\
\hline
\end{tabular}

Accumulating snow is a mixture of ice, air, and if warm enough, liquid water. Rain and snow mixed is most commonly named as sleet can occur where the temperature in the lower part of the atmosphere is slightly above the freezing point.

There exists high degree of positive correlation between total lightning flash counts and snow mixing ratio (Table 4). That means as the snow mixing ratio (qsnow) increases then the total lightning flash counts is also increased. In statistics, the p-value is the probability of obtaining results at least as extreme as the observed results of a statistical hypothesis test, assuming that the null hypothesis is correct. Here, Karl Pearson coefficient of correlation is 0.982 and significant $\mathrm{P}$ - value is 0.121 which is less than 0.15 , so the null hypothesis may get rejected at $15 \%$ level of 
significance. That means, the relationship between total lightning flash counts and qsnow is statistically significant.

For the case of graupel the correlation is also calculated. There exists high degree of positive correlation between total lightning flash counts and graupel mixing ratio (Table 4). That means as the graupel mixing ratio (qgraup) increases then the total lightning flash counts is also increased. Here, Karl Pearson coefficient of correlation is 0.981 and significant $\mathrm{P}$ - value is 0.125 which is less than 0.15 , so we may reject our null hypothesis at $5 \%$ level of significance. That means, the relationship between total lightning flash counts and qgraup is statistically significant.

The correlation between flash counts and cloud mixing ratio is also presented in the Table 4 . There exists high degree of positive correlation between total lightning flash counts and cloud mixing ratio. That means as the cloud mixing ratio (qcloud) increases then the total lightning flash counts is also increased. Here, Karl Pearson coefficient of correlation is 0.999 and significant $\mathrm{P}-$ value is 0.032 which is less than 0.05 , so we may reject our null hypothesis at $5 \%$ level of significance. That means, the relationship between total lightning flash counts and qcloud is statistically significant.

There exists high degree of positive correlation between Total lightning flash counts and vapour water mixing ratio (Table 4). That means as the vapour water mixing ratio (qvapor) increases then the total lightning flash counts is also increased. Here, Karl Pearson coefficient of correlation is 0.920 and significant $\mathrm{P}$ - value is 0.257 which is greater than 0.15 , so we may accept our null hypothesis at $5 \%$ level of significance. That means, the relationship between total lightning flash counts and qvapor is statistically insignificant.

\section{CONCLUSIONS}

A legitimate relationship between Lightning activity and micro-physical properties by using INSAT3DR Data, LIS_ISS data and WRF model simulated data has been studied in this paper. In this study it is found that model derived rainfall, vapour water mixing ratio and convective available potential energy are related with the lightning flash rate with some temporal and spatial error. The WRF simulated CAPE values are
$1618 \mathrm{~J} / \mathrm{kg}, 3275 \mathrm{~J} / \mathrm{kg}$ and $1023 \mathrm{~J} / \mathrm{kg}$ for case_1, case_2 and case_3 respectively and the observed values are $1299 \mathrm{~J} / \mathrm{Kg}, 3150 \mathrm{~J} / \mathrm{kg}, 1221 \mathrm{~J} / \mathrm{kg}$. Sensitivity of lightning occurrences with one indices, upper atmospheric condition and dew point temperature are also studied. The correlation analysis between total lightning flash occurrence and micro-physical parameters (snow, graupel, cloud, vapour water mixing ratio) over Bangladesh is also studied and found statistically significant relationship between the flash count and the cloud microphysical parameters. From the analysis of CAPE, vapour water mixing ratio, rainfall and thermodynamics condition of atmosphere with total lightning activity, we can conclude that maximum total lightning occurs at the location of high altitude. For Bangladesh, it is shown that north-east and north-west part of the country faced maximum total lightning activity. INSAT-3DR satellite data are used to determine the WRF model efficiency by comparing INSAT-3DR observed water vapour count with WRF model simulated vapour water mixing ratio (qvapor). A very strong and high degree of positive correlation between total lightning flash counts and cloud microphysical parameters are observed.

\section{REFENCES}

Albrecht, R., Goodman, S., Buechler, D., and Chronis, T. (2009). Tropical frequency and distribution of lightning based on 10 years of observations from space by the lightning imaging sensor (LIS). In Prepr. Fourth Conf. Meteorol. Appl. Light. Data, Phoenix, AZ, American Meteorological Society, p. 2-12.

Battan, L. J. (1965). Some factors governing precipitation and lightning from convective clouds. Journal of the Atmospheric Sciences, 22(1): 79-84.

Brooks, C. E. P. (1925). The Distribution of Thunderstorms over the Globe. Geophys. Mem., 3(24): 147-164.

Das, S. (2010). Climatology of thunderstorms over the SAARC region. SAARC Meteorological Research Centre.

Das, S. (2017). Severe Thunderstorm Observation and Modeling-A Review. Vayu Mandal, 43(2): 1-29.

Dewan, A., Hossain, M. F., Rahman, M. M., Yamane, Y., and Holle, R. L. (2017). Recent lightning-related fatalities and injuries in Bangladesh. Weather, climate, and society, 9(3): 575-589.

Gomes, C., Ahmed, M., Abeysinghe, K. R., and Hussain, F. (2006). Lightning accidents and awareness in South Asia: experience in Sri Lanka and 
Bangladesh. In Proceedings of the $28^{\text {th }}$ International Conference on Lightning Protection (ICLP): p. 18-22.

Goodman, S. J., Buechler, D. E., Knupp, K., Driscoll, K., and McCaul Jr, E. W. (2000). The 1997-98 El Nino event and related wintertime lightning variations in the southeastern United States. Geophysical Research Letters, 27(4): 541-544.

Goodman, S. J., and Christian, H. J. (1993). Global observations of lightning. Atlas of Satellite Observations Related to Global Change, RJ Gurney, JL Foster, and CL Parkinson, Eds. Cambridge University Press.

Hamid, E. Y., Kawasaki, Z., and Mardiana, R. (2001). Impact of the 1997-98 El Niño event on lightning activity over Indonesia. Geophysical Research Letters, 28(1): 147-150.

Holle, R. L. (2016). Lightning-caused deaths and injuries related to agriculture. In Preprints of the $33^{\text {rd }}$ international conference on lightning protection, Estoril, p. 25-30.

Holle, R. L., López, R. E., and Zimmermann, C. (1999). Updated recommendations for lightning safety-1998. Bulletin of the American Meteorological Society, 80(10): 2035-2042.

Kandalgaonkar, S. S., Tinmaker, M. I. R., Kulkarni, J. R., Nath, A., Kulkarni, M. K., and Trimbake, H. K. (2005). Spatio-temporal variability of lightning activity over the Indian region. Journal of Geophysical Research: Atmospheres, 110 (D11).

Kar, S. K., Liou, Y.-A., and Ha, K.-J. (2009). Aerosol effects on the enhancement of cloud-to-ground lightning over major urban areas of South Korea. Atmospheric Research, 92(1): 80-87.

Mansell, E. R., and Ziegler, C. L. (2013). Aerosol effects on simulated storm electrification and precipitation in a two-moment bulk microphysics model. Journal of the Atmospheric Sciences, 70 (7): 2032-2050.

Murugavel, P., Pawar, S. D., and Gopalakrishan, V. (2014). Climatology of lightning over Indian region and its relationship with convective available potential energy. International Journal of Climatology, 34(11): 3179-3187.

Nath, A., Manohar, G. K., Dani, K. K., and Devara, P. C. S. (2009). A study of lightning activity over land and oceanic regions of India. Journal of Earth System Science, 118(5): 467.

Piepgrass, M. v, Krider, E. P., and Moore, C. B. (1982). Lightning and surface rainfall during Florida thunderstorms. Journal of Geophysical Research: Oceans, 87(C13): 11193-11201.
Ranalkar, M. R., and Chaudhari, H. S. (2009). Seasonal variation of lightning activity over the Indian subcontinent. Meteorology and Atmospheric Physics, 104(1-2):125-134.

Reeve, N., and Toumi, R. (1999). Lightning activity as an indicator of climate change. Quarterly Journal of the Royal Meteorological Society, 125(555): 893-903.

Siingh, D., Buchunde, P. S., Singh, R. P., Nath, A., Kumar, S., and Ghodpage, R. N. (2014). Lightning and convective rain study in different parts of India. Atmospheric Research, 137: 35-48.

Stolz, D. C., Rutledge, S. A., and Pierce, J. R. (2015). Simultaneous influences of thermodynamics and aerosols on deep convection and lightning in the tropics. Journal of Geophysical Research: Atmospheres, 120(12): 6207-6231.

Tinmaker, I. R., and Chate, D. M. (2013). Lightning activity over India: a study of east-west contrast. International Journal of Remote Sensing, 34(16): 5641-5650.

Williams, Earle R. (1992). The Schumann resonance: A global tropical thermometer. Science, 256(5060): 1184-1187.

Williams, Earle R. (1994). Global circuit response to seasonal variations in global surface air temperature. Monthly Weather Review, 122(8): 1917-1929.

Williams, Earle R. (1995). Meteorological aspects of thunderstorms. Handbook of Atmospheric Electrodynamics, 1: 27-60.

Williams, Earle R. (2001). The electrification of severe storms. In Severe Convective Storms, p. 527-561. Springer.

Williams, E R. (2005). Lightning and climate: A review. Atmospheric Research, 76(1-4): 272-287.

Williams, E., Rosenfeld, D., Madden, N., Gerlach, J., Gears, N., Atkinson, L., et al. (2002). Contrasting convective regimes over the Amazon: Implications for cloud electrification. Journal of Geophysical Research: Atmospheres, 107(D20), LBA-50.

Williams, ERSA RUTLEDGE, Geotis, S. G., Renno, N., Rutledge, S. A., Rasmussen, E., and Rickenbach, T. (1992). A radar and electrical study of tropical "hot towers." Journal of the Atmospheric Sciences, 49 (15): 1386-1395.

Yuan, T., Remer, L. A., Pickering, K. E., and Yu, H. (2011). Observational evidence of aerosol enhancement of lightning activity and convective invigoration. Geophysical Research Letters, 38(4). 